\title{
Research on Transformation and Upgrading of Sports Industry in Wuhan Economic and Technological Development Zone under Low Carbon Concept
}

\author{
Di Zhang ${ }^{1, *}$ \\ ${ }^{1}$ School of Physical Education and Equestrian, Wuhan Business University, Wuhan, China
}

\begin{abstract}
Sports industry is a sunrise industry and is well recognized as a new green economic growth point. Wuhan, as the capital of Hubei Province, is giving full play to the city spirit of "daring to be the first and pursuing excellence" in the field of sports, and its sports industry is advancing at a rapid pace. As the first national sports industry demonstration base of Wuhan, the Wuhan Economic and Technological Development Zone (WHDZ) has a strong sports foundation and a collection of brand sports events. With great development potential in sports industry, WHDZ should take bold innovation with low carbon concept so as to better achieve the goal of high quality transformation and upgrading of sports industry in this region.
\end{abstract}

\section{Introduction}

Since long ago, the state attaches great importance to the development of sports industry, and has issued a number of policies and documents to support and protect. In October 2014, the State Council issued the Opinions on Accelerating the Development of Sports Industry and Promoting Sports Consumption, which elevated national fitness to a national strategy, and supported the sports industry as a green industry and a sunrise industry. The opinions emphasize the need to promote the sports industry as an important force for economic transformation and upgrading, and put forward support initiatives in 7 areas, striving to achieve a total sports industry size of more than 5 trillion yuan by 2025 [1].

In September 2019, the State Council issued the "Outline for the building of a leading Sports nation", which once again proposed to accelerate the development of the sports industry, improve the entire sports industry chain, promote the integrated development of sports and related industries, and promote the synergistic development of regional sports industries. In October 2020, the Fifth Plenary Session of the 19th CPC Central Committee proposed to "accomplish the building of a leading sports nation and a healthy China by 2035 ".

In order to implement the policies of the Party and the State on sports industry, the People's Government of Hubei Province issued the "Opinions on Accelerating the Transformation of Development and Promoting the Construction of a Strong Sports Province, which put forward 20 opinions from 5 aspects to promote the construction of a strong sports province, and has achieved notable results.

In October 2020, the China-Hubei Sports Industry Exchange Conference was held in Wuhan, and relevant data about Hubei's sports industry were released accordingly [2].

Table1. Overview of Sports Industry Data in Hubei

\begin{tabular}{|c|c|c|c|}
\hline No. & Item & Data & Remarks \\
\hline 1 & $\begin{array}{l}\text { national sports } \\
\text { industry bases }\end{array}$ & 13 & $\begin{array}{l}\text { Ranked } 7^{\text {th }} \text { in } \\
\text { China and } 1^{\text {st }} \text { in } \\
\text { central China }\end{array}$ \\
\hline 2 & $\begin{array}{l}\text { National-level } \\
\text { sports towns }\end{array}$ & 6 & $\begin{array}{c}\text { Jingmen Zhanghe } \\
\text { New District, } \\
\text { Yichang Xingshan } \\
\text { County, Xiaogan } \\
\text { Xiaochang County, } \\
\text { Xiaogan Dawu } \\
\text { County, Jingzhou } \\
\text { Songzi City, } \\
\text { Jingmen Jingshan } \\
\text { County } \\
\end{array}$ \\
\hline 3 & $\begin{array}{l}\text { National sports } \\
\text { consumption } \\
\text { pilot cities }\end{array}$ & 2 & Yichang, Jingmen \\
\hline 4 & $\begin{array}{l}\text { Hubei sports } \\
\text { industry scale } \\
\text { achieved }\end{array}$ & $\begin{array}{l}\text { Over } 150 \\
\text { billion } \\
\text { yuan }\end{array}$ & In 2019 \\
\hline 5 & $\begin{array}{l}\text { Hubei sports } \\
\text { industry scale } \\
\text { expected }\end{array}$ & $\begin{array}{l}\text { Over } 300 \\
\text { billion } \\
\text { yuan }\end{array}$ & by 2025 \\
\hline
\end{tabular}

Wuhan, as the capital of Hubei Province, is giving full play to its city spirit of "daring to be the first and pursuing excellence" in the field of sports, with the sports industry advancing by leaps and bounds and evolving at a rapid pace. In recent years, international and domestic largescale events such as the Military World Games, the Wuhan

\footnotetext{
*Corresponding author: 601628914@qq.com
} 
Open, the Wuhan Marathon and the Wuhan Marathon Swimming have been held in Wuhan successively, driving the development of hotels, attractions, malls, entertainment and other service industries, making sports the city's name-card and greatly enhancing the international image and influence of Wuhan. In overall views, the development of sports industry has plenty of policies and good prospects, but in the background of the global economy emphasizing low-carbon transformation, highlighting the concept of carbon neutrality, if the sports industry wants to have a good, long and strong future, it must follow the international economic trend and market situation, actively adjust the development model, promote the transformation and upgrading of sports industry development with low-carbon concept, and make it a new green and healthy economic growth point in urban development.

\section{Current Situation of Sports Industry Development in Wuhan Economic and Technological Development Zone}

\subsection{Well established industrial foundation}

The first is the gathering of talents in sports industry. The main industry in WHDZ is the manufacturing industry represented by the automobile sector, but in recent years, it has taken the initiative to seek transformation and development, and has strongly supported the development of modern service industry represented by the sports industry.

Benefiting from the convenient and excellent transportation network of WHDZ and the high-standard and advanced stadiums, large events and sports activities are continuously being landed here, thus gradually forming mature teams of sports operation and sports professionals with rich experience in event management. In addition, there are two major provincial and municipal universities in the region: Jianghan University and Wuhan Business University.

Both universities have physical education schools and Jianghan University has three undergraduate majors in physical education, sports training and social sports guidance and management, as well as one undergraduate major in golf. Wuhan Business University' College of Physical Education currently offers three undergraduate majors including Sports Economics and Management, Leisure Sports and Sports Rehabilitation. In 2009, the university co-founded the first equestrian college in China, and in 2010, it established the country's first Institute of Horse Racing Economics (now renamed Wuhan Institute of Horse Industry). The two universities have trained and delivered thousands of sports talents to the society in recent years, and many graduates have stayed in the WHDZ, playing an active role in the innovation and development of the sports industry here, which is a valuable sports talents resource for WHDZ.

Secondly, the sports facilities are top-notch. Both Wuhan City and WHDZ attach great importance to the planning and construction of sports facilities in this area, and through years of development, there is a series of advanced sports supporting venues and facilities, which provide a strong hardware guarantee for sports events and activities.

Table2. List of major large-scale stadiums in WHDZ

\begin{tabular}{|c|c|c|c|}
\hline No. & Venue & Scale & Features \\
\hline 1 & $\begin{array}{l}\text { Wuhan } \\
\text { Sports Center } \\
\text { Stadium }\end{array}$ & $\begin{array}{c}\text { Construction area } \\
\text { of } 80,445 \text { square } \\
\text { meters, } 105 \times 68 \mathrm{~m} \\
\text { standard natural } \\
\text { turf soccer field, } 8 \\
\text { standard } 400 \mathrm{~m} \\
\text { running tracks } \\
\end{array}$ & $\begin{array}{l}60,000- \\
\text { person mega- } \\
\text { stadium }\end{array}$ \\
\hline 2 & $\begin{array}{l}\text { Wuhan } \\
\text { Sports Center } \\
\text { Gymnasium }\end{array}$ & $\begin{array}{l}\text { Covering an area of } \\
28,830 \mathrm{~m} 2 \text { with a } \\
\text { building area of } \\
53,919 \mathrm{~m} 2 \text { and with } \\
\text { a capacity of } \\
\text { more than } 13,000 \\
\text { people }\end{array}$ & $\begin{array}{l}\text { Largest } \\
\text { cable- } \\
\text { supported } \\
\text { dome steel } \\
\text { structure in } \\
\text { Asia }\end{array}$ \\
\hline 3 & $\begin{array}{l}\text { Wuhan } \\
\text { Sports Center } \\
\text { Aquarium }\end{array}$ & $\begin{array}{c}\text { Building area of } \\
33547 \mathrm{~m} 2,3209 \\
\text { seats }\end{array}$ & $\begin{array}{l}\text { Comprehensi } \\
\text { ve national } \\
\text { fitness centre }\end{array}$ \\
\hline 4 & $\begin{array}{l}\text { WHDZ } \\
\text { Football Park }\end{array}$ & $\begin{array}{l}\text { Total land area of } \\
100,000 \text { square } \\
\text { meters, } 14 \text { artificial } \\
\text { turf soccer fields, } \\
\text { with turf quality } \\
\text { meeting the highest } \\
\text { two-star FIFA } \\
\text { artificial turf } \\
\text { certification } \\
\text { standard }\end{array}$ & $\begin{array}{l}\text { Largest } \\
\text { soccer park } \\
\text { in central } \\
\text { China }\end{array}$ \\
\hline 5 & $\begin{array}{l}\text { Modern Land } \\
\text { Beyond Sky } \\
\text { 18-hole } \\
\text { course Golf } \\
\text { Club }\end{array}$ & $\begin{array}{l}\text { Covering an area of } \\
\text { about } 2,500 \text { acres }\end{array}$ & $\begin{array}{c}\text { PGA } \\
\text { standards } \\
\text { with a total } \\
\text { length of } \\
7,612 \text { yards } \\
\end{array}$ \\
\hline 6 & $\begin{array}{l}\text { Jianghan } \\
\text { University } \\
\text { Gymnasium }\end{array}$ & $\begin{array}{l}\text { Building area of } \\
15511 \text { square } \\
\text { meters, } 2500 \text { seats, } \\
28 \text { meters high }\end{array}$ & $\begin{array}{c}\text { Hi-tech } \\
\text { coating film }\end{array}$ \\
\hline 7 & $\begin{array}{l}\text { Wuhan } \\
\text { Business } \\
\text { University } \\
\text { Swimming } \\
\text { Centre }\end{array}$ & $\begin{array}{l}\text { Construction area } \\
\text { of } 14470 \text { square } \\
\text { meters, containing } \\
1 \text { international } \\
\text { standard lane } \\
\text { competition pool } \\
\text { and } 1 \text { training pool, } \\
500 \text { spectators seats }\end{array}$ & $\begin{array}{c}\text { BIM } \\
\text { technology }\end{array}$ \\
\hline
\end{tabular}

Third is the advantage of the policies. WHDZ is vigorously developing modern service industry and promoting the integration of industry and urban areas. In 2019, WHDZ was approved by the State General Administration of Sports as a national sports industry demonstration base becoming Wuhan's first "national sports industry demonstration base. The city of Wuhan is also supporting the WHDZ in terms of policy to build the future sports city and racing city of China.

\subsection{High specifications of competition events}

A large number of international and domestic top-level events have been held in WHDZ, with an average of more 
than 40 large events held each year. The top-class event venues, good sports competition culture, the atmosphere of hosting events and successful events have attracted more top international and domestic events to choose to hold events here. The major large-scale events in recent years include: Men's Football World Cup Qualifier, Women's World Cup, Men's Basketball World Cup, Diving World Championship, World Aviator Congress, World Military Games, Asian Badminton Championship, Aviation Championship, City Games of the People's Republic of China; China Motorcycle Sports Congress, etc.

\subsection{Rich layout of sports industry}

WHDZ is focusing on building a multi-dimensional sports industry pattern and providing rich sports product supply and services. Based on the existing situation, it fully integrates its advantages of geography, recourses and policies, and takes into account the potential development factors, focusing on the layout of featured projects such as ice-snow, racing and soccer, and striving to make them into high-quality event IPs. The rich industrial layout will strongly boost the development of sports industry.

\section{Opportunities and Challenges of Sports Industry in WHDZ under Low Carbon Concept}

\subsection{Highly compatibility between the orientation of the development of WHDZ and the concept of transformation and upgrading of sports industry}

WHDZ was established in 1991, and the area under its jurisdiction has expanded four times to 489.7 square $\mathrm{km}$, an increase of nearly 50 times; the GDP in 2020 is close to 170 billion yuan [3], ranking 8 th among national-level economic and technological development zones and first in the central and western regions. Currently, WHDZ is comprehensively promoting the "five transformations". In the context of the national strategy of a healthy China and a strong sports nation, the development orientation of WHDZ coincides with the concept of transformation and upgrading of the sports industry and green innovation.

\subsection{Upward trend of sports industry bringing unprecedented development potential for WHDZ}

With the continuous development of social economy and the improvement of people's material living conditions, the demand for sports is growing, and the sports industry, as a sunrise industry, is also an innovative field for green and low-carbon development. The sports industry is also improving through innovations, and people's motivation for sports fitness, leisure and consumption is increasing, which is the primary motivation for the sports industry market to grow, and this rising motivation and trend will drive more people to participate in the sports industry, engaging in sports event services, management, product innovation, and other aspects of the industry chain. The sports industry is low-carbon and environmentally friendly compared to other industries, and has a stimulating effect on the regional economy, combining with the good development trend of sports industry, the future development potential of WHDZ is unlimited.

\subsection{Enriching the leisure life of the masses and driving economic growth}

The early planning of WHDZ was based on the development of manufacturing industry, with many factories and enterprises. Compared with other main urban areas, the commercial and leisure service facilities were seriously inadequate, and the public had nowhere to go for leisure and fitness entertainment, resulting in the lack of regional vitality. With the emphasis on urban functions in WHDZ in recent years, the deployment of commercial and leisure service facilities has been rapidly established, which has not only enriched the leisure life of the masses and met the diversified sport needs, but also driven the consumption of sports industry. Moreover, the holding of various events has brought a number of people and visitors to WHDZ, which in turn has led to a series of industries such as accommodation, catering, tourism and sightseeing, boosting jobs, promoting consumption and driving economic growth.

\section{Path exploration for the transformation and upgrading of sports industry in WHDZ}

\subsection{Strengthening the overall planning and design of the sports industry in WHDZ from the perspective of low-carbon development}

It is important to further strengthen the overall planning and design of the sports industry from the current situation of WHDZ, fully consider the current development trend of the sports industry, conduct a comprehensive analysis from the perspective of low-carbon development, and make scientific sports industry planning for the spatial layout, development positioning, industrial chain, economic drive and environmental impact of the development of the sports industry in the region. Social forces should be vigorously introduced to participate in the sports industry. It is necessary to actively introduce social forces to participate in the sports industry, introduce supporting policies, and give certain rewards or preferential policies to those who make outstanding performance in the innovation of low-carbon green sports industry.

\subsection{Innovation in the operation and management of existing events with low carbon concept}

In order to innovate the operation and management of the event, the "green" concept and technology should be added to sports events, and there are several famous events in WHDZ which are highly related to the local industry, such as China Automobile and Motorcycle 
Sports Festival and the World Fly-in Expo. Such events are often considered to be highly polluting, energy intensive and not green or environmentally friendly. If a new series of innovations are made to the events through low-carbon concepts, the impressions and perceptions of the public can be drastically changed, and energy saving and emission reduction can be achieved. For example, we can set up a new energy racing section in a traditional fuel car event, so as to showcase the technology and promote the application of new energy vehicles through the event, and raise the public's attention to new energy vehicles and environmental awareness. The World Fly-in Expo is located in a remote area of Hannan District, where public transportation is extremely inconvenient and the main way to get to the race is by self-driving. Since WHDZ is developing new energy automatic driving vehicles, it is possible to set up shared new energy automatic driving buses and cab routes for teams and spectators to use, which will promote the region's high-tech industry and put into practice the concept of shared travel and green lowcarbon organization of competitions.

\subsection{Enriching sports industry patterns and developing new low-carbon sports sectors}

At present, the sports industry pattern of WHDZ is still mainly sports events and leisure sports activities, although it has produced the economic benefits and social influence of event gathering, but the industrial pattern is still relatively single and not rich enough. WHDZ should further increase the introduction of sports industry companies and the level of incubation of local sports enterprises, and comprehensively expand the industrial patterns in such segments as new sports equipment manufacturing, sports software companies, sports service marketing, and event management and operation.

\subsection{Facilitating energy saving and emission reduction in sports stadium facilities with low carbon strategies}

With the gradual increase of WHDZ events, how to use the stadium facilities efficiently is a realistic question at hand. It is not easy to answer this question correctly, and what is needed is not only the awareness of energy saving and emission reduction, but also the joint mutual assistance mechanism of the whole sports industry chain [4]. Energy saving and emission reduction work should be carried out in all aspects of the stadium before, during and after the game, so it is imperative for the relevant departments to jointly supervise the implementation of low-carbon work and jointly evaluate and test the effect of low-carbon work. The competent departments should create a favorable macro external environment and internal incentive mechanism for the whole sports industry chain, such as promoting green marketing of events, enhancing the civilized etiquette and environmental awareness of spectators, mobilizing the main role and enthusiasm of low-carbon operation of venue management teams, and strengthening the use of venues after the games and promoting the sharing and opening of venues to the public. Through the joint efforts of all participating parties, we can really make the venues run energy-efficiently, while effectively improving the utilization rate, reducing and shortening the vacancy period, and avoiding the unwarranted waste of sports hardware resources.

\section{Conclusion}

Sports industry, as an environment-friendly industry, is a green sunrise industry [5]. WHDZ has a strong sports foundation, a collection of brand events, and has been approved as a national sports industry demonstration base by the State General Administration of Sports, and the development potential of sports industry is promising. WHDZ is currently in a critical period of industrial upgrading and structural adjustment, and it should take sports as a new economic growth point, combine with regional advantages, vigorously develop The sports industry, take bold innovation in sports events, sports services, sports marketing and sports tourism with low carbon concept, and promote the transformation and upgrading of sports industry and high quality development.

\section{References}

1. Xinhua News Agency, the Opinions on Accelerating the Development of Sports Industry by the State Council, 2014.10, http://www.gov.cn/xinwen/201410/20/content_2767791.htm

2. Chutian Traffic Radio, Sports industry in Han "restart"! Hubei has come up with a "Hubei program" for the development of sports industry, 2020.10, https://www.sohu.com/a/428673071_355692

3. Yu Lingyun, Young in 30 years of progress, WHDZ released a music video to show its charm, 2021.5, https://xw.qq.com/cmsid/20210529A03WZK00

4. Liao Chunhai." The direction of low-carbon sports tourism development in China." Journal of Sports $18.04 \quad$ (2011):53-56. doi:10.16237/j.cnki.cn441404/g8.2011.04.030.

5. Wang Yan. "Analysis of low carbon development strategy of sports industry from the perspective of sports economy." Journal of Economic Research .04 (2017):147-148. doi:CNKI:SUN:JJYD.0.2017-04068 . 